\title{
On the occasion of the 100th anniversary: Ernst Späth and his mescaline synthesis of 1919
}

\author{
Rudolf Werner Soukup ${ }^{1}[$
}

Received: 11 December 2018 / Accepted: 18 March 2019 / Published online: 29 April 2019

(c) The Author(s) 2019

\begin{abstract}
Characterizing plant ingredients has been the main topic of chemical research at the University of Vienna since the beginning of the last half of the nineteenth century, especially at the IInd Chemical Institute (founded in 1870). The remarkable success in many fields of natural organic product structure elucidation was in part the result of the discovery of important identifying reactions of functional groups in organic molecules by Austrian chemists, e.g., Lieben's iodoform test, the Herzig-Meyer's method for the determination of methylamino groups or Zeisel's method for the determination of methoxy groups in organic compounds. Ernst Späth was the most prominent exponent of the Viennese school of phytochemistry. He and his coworkers identified more than 120 phytochemical substances. His mescaline synthesis of 1919 has marked a milestone in the chemistry of organic natural products.
\end{abstract}

\section{Graphical abstract}

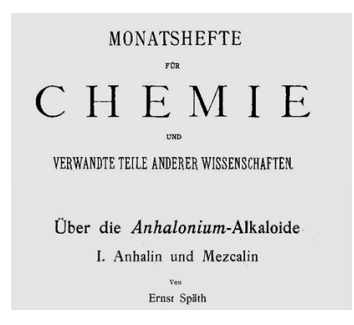

Keywords Mescaline $\cdot$ Natural product chemistry $\cdot$ Total synthesis

\section{Introduction}

Without doubt, Ernst Späth was the most prominent exponent of the Viennese school of phytochemistry, and his synthesis of mescaline in 1919 has marked a milestone in organic natural product chemistry.

The history of natural product investigation in the Austro-Hungarian Empire started when Joseph Redtenbacher (1810-1870) was appointed chair of chemistry at the University of Prague in 1840 [1]. Redtenbacher had been a

Rudolf Werner Soukup

rudolf.werner@kabelnet.at

1 Institute of Inorganic Chemistry, Functional Materials, University of Vienna, Vienna, Austria student of Joseph Franz von Jacquin (1766-1839) in Vienna. Joseph Franz von Jacquin himself was strongly influenced by Antoine de Lavoisier. Joseph Franz von Jacquin succeeded his father Nicolaus Joseph von Jacquin (1727-1817) in 1797 as professor of botany and chemistry at the medical faculty. The interconnection of research on plants and their extracts at that time is obvious [2]. In 1849, Redtenbacher received a call to establish a chair of chemistry at the philosophical faculty of the University of Vienna. Redtenbacher's achievements include the discovery of acrolein and acrylic acid, the elucidation of the fermentation process of glycerin by baker's yeast, and his research on taurine.

Redtenbacher had many important students. One of them was Heinrich Hlasiwetz (1825-1875). Hlasiwetz investigated quercetin, quercitrin, and discovered phloroglucinol in phloretin [3], which can be isolated from the 
bark of fruit trees. Hlasiwetz's successor as professor at the University of Innsbruck was Ludwig Barth von Barthenau (1839-1890), when Hlasiwetz went to Vienna in 1867. Together with Hlasiwetz, Barth had obtained resorcinol from ammoniated resin gum. In 1876, Barth became professor at the Ist Chemical Institute of Vienna. In 1880, he and his student Michael Kretschy isolated the alkaloids picrotin and picrotoxinin from Indian cocculus [4].

Barth's successor was Hugo Weidel (1849-1899), who was especially interested in cinchonine alkaloids. The identification of nicotinic acid as an oxidation product of nicotine in 1873 [5] and Weidel's finding of the formula of berberonic acid in 1879 [6] marked further milestones in early Austrian alkaloid chemistry. In 1880, Weidel performed the first synthesis of a hydroxyquinoline together with his student Albert Cobenzl [7]. As a result, useful reagents became available.

Temporarily, the founder of pharmaceutical chemistry Josef Herzig (1853-1923) was appointed interim director of the Ist Institute (1899-1902). Prior to his appointment, between 1894 and 1897, Herzig and his colleague Hans Meyer (1871-1942) had developed the Herzig-Meyer alkylamino group determination [8-10]. Herzig's successor thereafter was Rudolf Wegscheider (1859-1935), a former PhD student of Ludwig Barth. Wegscheider's first papers described various natural products, e.g., isovanillin [11]. But after a study stay with Hans Heinrich Landolt in Berlin in 1883, Wegscheider became interested in chemical kinetics. Today, Wegscheider is considered the founder of physical chemistry in Vienna.

At the IInd Chemical Institute of the University of Vienna, Friedrich Rochleder (1819-1874), a friend of Redtenbacher, had been professor of general and pharmaceutical chemistry, since 1870 . Rochleder gained an excellent reputation in phytochemistry. He published on quercetin, on aesculin, on tannins, on caffeine, and developed a procedure for the extraction of pure alizarin from madder root [12]. He was later succeeded by Adolf Lieben (1876-1906), who was addressed as the doyen of organic chemistry [13]. In 1870, Lieben published a method of decomposing methylketones-the so-called iodoform reaction after Lieben $[14,15]$. In an official speech at the Austrian Academy of Sciences, Ernst Späth paid tribute to Lieben's achievements regarding phytochemistry: "The investigations of Lieben and Haitinger on chelidonic acid, found in Chelidonium majus, are significant. This was the first time a pyrone ring was discovered and the relationship of this ring system to the pyridine ring was revealed" [16].

In 1883, Simon Zeisel (1854-1933), a student of Lieben, tried to elucidate the structure of colchicine [17], the main alkaloid in meadow saffron. Zeisel proposed a test reaction for colchicine and related compounds [18] that is still used today: the Oberlin-Zeisel reaction. Well known is also Zeisel's determination of methoxy groups.

After Lieben's retirement in 1906, his pupil Zdenko Hans Skraup (1850-1910) was appointed professor at the IInd Institute. Skraup was successful in elucidating the structure of some quinoline alkaloids. In 1880, he discovered a synthesis of quinoline [19], which was named after him. When Skraup died unexpectedly at the age of 60 in 1910, the ministry of education decided that Prof. Guido Goldschmiedt (1850-1915) should move from Prague to Vienna. Goldschmiedt had previously contributed to the knowledge on flavones, on ellagic acid, on scutellarin, etc. His constitution analysis of papaverine represents the first determination of an opium alkaloid structural formula [20].

\section{Späth's mescaline synthesis of 1919}

"Since Heffter's stoichiometric formula for mescaline $\mathrm{C}_{11} \mathrm{H}_{17} \mathrm{O}_{3} \mathrm{~N}$ was correct, one may make allowance for the formula 1 regarding the fact that the oxidized product of this alkaloid is trimethylgallic acid" [21]. This sentence marks the beginning of Ernst Späth's argumentation for a new hypothesis on the structural formula of mescaline. Arthur Heffter, at that time Liebreich Chair Professor at the Humboldt University Berlin, had previously determined the empirical formula of mescaline and had found that upon oxidation the base yields trimethylgallic acid [22]. Heffter synthesized $N$-(3,4,5-trimethoxybenzyl)methylamine and found that it was not identical but isomeric to mescaline. In his argumentation, Späth continued that no natural alkaloids of a benzylamine type had been reported up to date, whereas $\alpha$-phenyl- $\beta$-aminoethane derivatives were already known to be very common.

To verify his hypothesis that mescaline is indeed 2-(3,4,5-trimethoxy-phenyl)ethylamine, Späth reduced 3,4,5-trimethoxybenzoyl chloride to the corresponding aldehyde using the Rosenmund method, and further condensed this aldehyde with nitromethane yielding $\beta$-nitro3,4,5-trimethoxystyrene. Next, this styrene was reduced to the oxime using zinc dust and acetic acid, and the oxime further reduced to 2-(3,4,5-trimethoxy-phenyl)ethylamine (1) by sodium amalgam (Scheme 1) [23].

\section{Who was Ernst Späth?}

In 1919, Privatdozent Dr. Ernst Späth was an unknown 33-year-old assistant of Prof. Rudolf Wegscheider at the Ist Chemical Institute of the University of Vienna. He was born on May 14, 1886 in the small town Bärn in the Olomouc District of Moravia (today Moravský Beroun in the Czech Republic) as the son of a farrier. The hope 


\section{Scheme 1}<smiles>O=C(O)c1cc(O)c(O)c(O)c1</smiles><smiles>COc1cc(C(=O)O)cc(OC)c1OC</smiles>

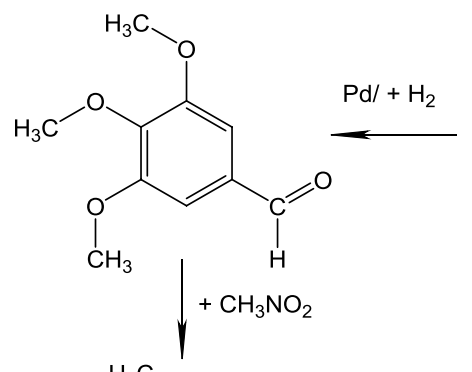<smiles>COc1cc(/C=C/[N+](=O)[O-])cc(OC)c1OC</smiles><smiles>COc1cc(CCN)cc(OC)c1OC</smiles>

1

of his father, Alois Späth, was that Ernst would succeed him as a smith. But his mother, Marie Späth, née Walter, strongly advocated that Ernst attended the "Realschule". In 1906, after passing additional examinations in Latin and Greek, Späth began to study natural sciences at the University of Vienna [24, 25]. In 1909, Späth's first scientific paper-written together with his doctoral supervisor Rudolf Wegscheider-was published in Chemical Monthly [26]. On July 16, 1910, Ernst Späth earned his doctoral degree with his thesis "Über die Anlagerung von Säureanhydriden an Aldehyde und Ketone". Already in 1913, he was interested in new possibilities of syntheses in connection with Grignard reagents. He published a new synthesis of stilbenes in 1914 [27] and a new synthesis of aldehydes in the following year [28]. Despite serving as an officer at the "Festungsartillerieregiment Nr. 4" at Brioni island in the Adriatric Sea during World War I, he published a paper on new derivates of opianic acid in 1916 together with Wegscheider [29]. In 1917, he not only habilitated in chemistry, but also married Anna Amalie Schmarek (1890-1986), whom he knew from childhood.

In July 1919, Späth could prove that Aribin (2), isolated from Arariba rubra Mart. by Reiner Rieth in 1861 [30], is identic to Harman, isolated from Peganum harmala and described by Otto Fischer in 1901 [31]: i.e., 1-methyl9H-pyrido[3,4-b]indole (2, Fig. 1) [32].

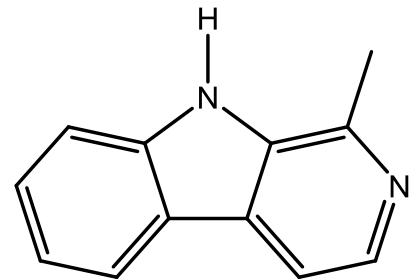

2

\section{Ordinarius at the IInd chemical institute}

When Wilhelm Schlenk (1879-1943)—since 1916 ordinarius at the IInd Chemical Institute - accepted a call to the Emil Fischer Chair at the University of Berlin in 1921, Adolf Franke (1874-1964) temporarily became head of the institute. Concerning Schlenk's succession, the Ministry of Education held hearings with Roland Scholl, Julius von Braun, Hans von Euler-Chelpin, and Karl Freudenberg, but all of them refused [33]. Finally, in 1924, Ernst Späth who had received the title of extraordinary professor in 1921 became ordinarius and director of the IInd Chemical Institute of the Viennese University. In 1926, he was elected to the Austrian Academy of Science as a full member. During the academic year 1932/33, he was dean of the philosophical faculty and 1937/38 rector of the University Vienna (Fig. 2).

His main field of work remained natural product chemistry. The results of his work on cytisine (3) (extracted from parts of the plant laburnum) [34] was decisive for being awarding the Ignaz-Lieben-Preis in 1920. In oxyacanthine and curine (a component of the arrow poison curare), he recognized two compounds derived from benzylisoquinoline (4) [35]. He was able to characterize the main alkaloid of celandine, chelidonine (5) [36-38], as well as tazettine (6) [39] (a narcissus alkaloid) by structural formulas. In 1921, Späth and Erich Tschelnitz [40] reported the constitutional formula of the pyridine alkaloid ricinine (7), isolated like the extremely poisonous ricin from Ricinus communis (Fig. 3).

In 1928, Späth and Hermann Bretschneider published the first synthesis of nicotine (Scheme 2) [41], whereby they confirmed the nicotine formula postulated by Adolf Pinner in 1893.

Späth especially came into prominence regarding the minor tobacco alkaloids. As an example, he identified anabasine (8) together with his research assistant Friederike Kesztler [42]. Späth's research on myosmine (9) (together with Adolf Wenusch and Emil Zajic [43]) led to a synthesis of myosmine, published together with Luigi Mamoli in 1936 [44]. In 1929, Späth and Otto Hromatka [45] proved a structural formula of apomorphine (10) proposed by Robert Pschorr, and in 1938, Späth and Wilhelm Gruber [46] 


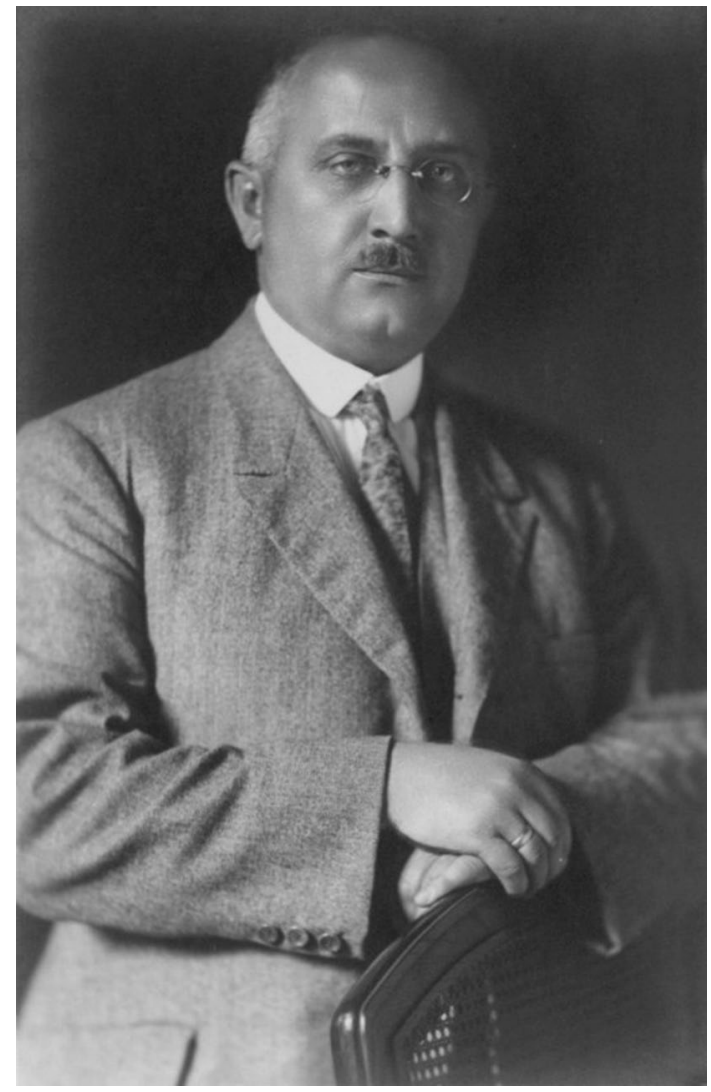

Fig. 2 Ernst Späth, photography 1927, Theo Bauer, Archiv der Universität Wien. Signatur: 106.I.1269 established the previously isolated khellin (11) (from Ammi visnaga L.) as a furochromone derivate (Fig. 4). Overall, Späth elucidated the constitution of more than 120 plant ingredients, especially tobacco alkaloids and coumarins.

\section{What happened after March 15, 1938?}

On March 15, 1938, the Austrian Ministry of Education issued an instruction for Dr. Fritz Knoll, botanist and NSDAP member, to take over the rectorate of the University of Vienna. On March 16, Knoll took over the official duties from former rector Ernst Späth and was, thus, appointed "Acting Rector" [47]. Although removed from his post as rector, Späth continued to hold the position of general secretary of the Austrian Academy of Sciences from 1938 to 1945. At an extraordinary session of the Academy on October 30, 1945, Späth was elected president of the Academy [48]. In 1946, Späth initiated a new foundation of the "Verein Österreichischer Chemiker" and was appointed member of the editorial board of Chemical Monthly. Späth died unexpectedly during a journey to Zurich on September 30, 1946.

\section{Späth's academic tree}

Späth had a great number of students. What follows is an arbitrary selection (Fig. 5).
Fig. 3 Structures of compounds 3-7

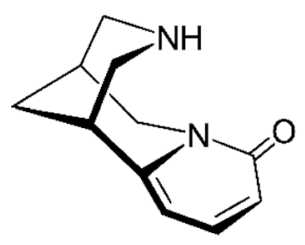

3<smiles>c1ccc(Cc2nccc3ccccc23)cc1</smiles>

4<smiles>CN1Cc2c(ccc3c2OCO3)[C@@H]2[C@@H](O)Cc3cc4c(cc3[C@@H]21)OCO4</smiles>

5

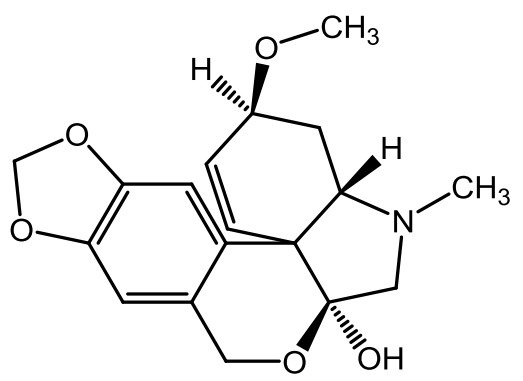

6<smiles>COc1ccn(C)c(=O)c1C#N</smiles> 
Scheme 2<smiles>[R]OC(=O)c1cccnc1</smiles><smiles>CNCCCC(O)c1cccnc1</smiles>

Prafulla Kumar Bose (1898-1983) was born in West Bengal. In 1922, he passed his M.Sc. Examination at Calcutta University, and in 1933, he proceeded to Europe, where he first worked with Prof Wieland and then with Prof Späth. In Vienna, he became interested in the chemistry of coumarins and continued his collaborative work with Späth even after returning to India. This resulted in the elucidation of some new coumarin structures from Indian plants [49].

Hermann Bretschneider (1905-1985) studied with Ernst Späth and Rudolf Wegscheider, graduated in 1928, became assistant at the Pharmacological Institute and later at the IInd Chemical Institute. From 1936 to 1940, he worked at the "Chinoinwerke" in Budapest and later at the company Boehringer/Ingelheim until 1946. He habilitated in 1947 and was appointed ordinarius at the newly founded Institute of Organic Chemistry at the University of Innsbruck in 1952. As a student of Späth, he mainly investigated the synthesis of compounds with potential pharmacodynamic effects [50].
Alfred Burger (1905-2000) was an American chemist of Austrian descent. With his thesis "Synthesen in der Reihe der Opiumalkaloide", he earned his $\mathrm{PhD}$ at the University of Vienna in 1928. From 1929, he was employed at the University of Virginia. Burger's focus was on medicinal chemistry, especially the mode of action, the chemical structure and the abuse of drugs. He was the founder and first editor-in-chief of the Journal of Medicinal Chemistry [51].

Holger Erdtman (1902-1989) studied chemistry at Stockholm University (at that time 'Stockholms Högskola'). He completed his thesis during the autumn of 1931 in the laboratories of Professors Fritz Fichter in Basel and Ernst Späth in Vienna. Before being appointed professor of organic chemistry at the Royal Institute of Technology in Stockholm, Holger Erdtman worked as a research fellow at the Swedish Forest Products Laboratory. Erdtman's most significant achievement was the structural elucidation of conifer tropolones. The fundamental importance of this work has been recognized not only by natural product chemists, but also by theoretical chemists [52].

Fritz Feigl (1891-1971) was not really a student of Späth. However, Späth actively supported Feigl following the definitive rejection of Feigl's application for habilitation at the Technische Hochschule due to his Jewish descent and his political attitude in 1926. One year later, Feigl was awarded with the venia docendi for experimental and analytical inorganic chemistry at the University of Vienna [53]. In 1924, Feigl married Dr. Regina Schorr, née Freier (1897-1976), one of his students at the laboratory of the IInd Chemical Institute. Feigl became famous for the
Fig. 4 Structures of compounds 8-11<smiles>c1cncc([C@H]2CCCCN2)c1</smiles>

8<smiles>CN1CCc2cccc3c2[C@H]1Cc1ccc(O)c(O)c1-3</smiles><smiles>c1cncc(C2=NCCC2)c1</smiles>

9<smiles>COc1c2occc2c(OC)c2c(=O)cc(C)oc12</smiles> 


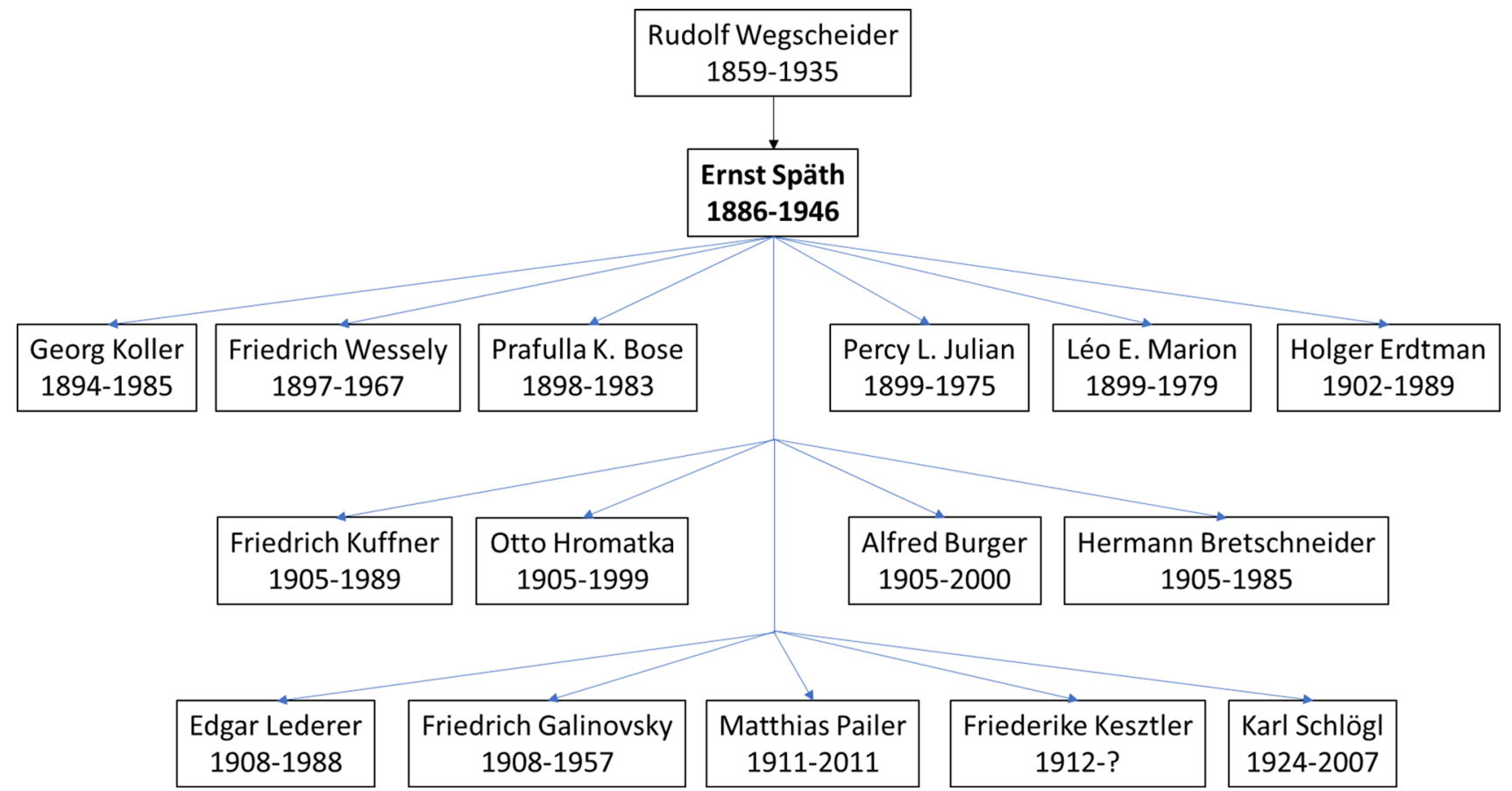

Fig. 5 Academic tree of Ernst Späth

development of his spot test analysis. In 1938, Feigl and his family emigrated via Switzerland, Belgium, France, and Portugal to Brazil.

Around 1936, Friedrich Galinovsky (1908-1957) discovered the tricyclic structure of cytisine (3) together with Späth [54]. This discovery is a good example for the progress achieved in the chemistry of natural products regarding complexity within two decades. Galinovsky was honored by being invited to write a review on "Lupine Alkaloid and Related Compounds" in the journal Progress in the Chemistry of Organic Natural Products in 1951. Späth himself was one of the editors of this journal [55].

Otto Hromatka (1905-1999) was a research assistant of Späth following his doctorate, earned in 1929. After ten years at the Merck KGaA in Darmstadt, Hromatka returned to Vienna in 1941 as a docent of organic chemistry. He became famous for his invention of submersed vinegar fermentation (together with Heinrich Ebner in 1949) [56]. From 1963 until his retirement in 1975, Otto Hromatka was Professor for organic chemistry at the Technische Hochschule in Vienna.

Percy Lavon Julian (1899-1975) was born in Montgomery, Alabama, as the son of a railway mail clerk and the grandson of slaves. Julian studied at DePauw University in Greencastle, Indiana, and completed a master's degree in organic chemistry at Harvard University. In 1929, Julian travelled to Vienna to begin his doctoral studies on the chemistry of medicinal plants. Two years later, he and a Viennese colleague, Josef Pikl (1904-1989), took positions back in the United States at Howard and two years later moved to DePauw University. There they accomplished the first total synthesis of physostigmine, the active principle of the Calabar bean, used since the end of the nineteenth century to treat glaucoma. In the 1940s, Julian produced steroids via stigmasterol from soybeans at the Glidden Company in Chicago [57].

Friederike Kesztler (married Kesztler Gandini) got an employment as Späth's research assistant in 1936. She was born in Hermannstadt (Nagyszeben, Sibiu) in Transylvania in 1912 and enrolled at the University of Vienna in 1931 [58]. With Späth, she published papers on anhalonidine, l-benzyltetrahydroisoquinoline, $N$-methylmyosmine, L-anatabine, L-anabasine, and D,L-nornicotine [42]. Obviously, she was dismissed in 1938. After the war, she continued her work "interrupted due to external circumstances". In 1952 and 1960, papers containing experimental results of her thesis from 1936 appeared in Chemical Monthly [59, 60].

The title of Georg Koller's (1894-1985) thesis (under Späth's academic supervision) was "Über die Konstitution und Synthese des Ricinins". From 1924, Koller worked at the IInd Chemical Institute and published on pseudoephedrine, coniine, acridine, acridic acid, and acridone. In the 1930s, he became a specialist on lichen acid chemistry. In 1936, he joined the NSDAP and during World War II, he served as a contact man between the university and NSDAP. In 1945, he was discharged [61].

Together with Friedrich Kuffner (1905-1989), Späth wrote the concluding contribution of volume 2 of the 
monograph series "Progress in the Chemistry of Organic Natural Products" in 1939, entitled "Tobacco Alkaloids". Kuffner was Späth's assistant from 1936 to 1941 [62]. From 1948 on, he headed a department at the IInd Chemical Institute. In 1954, Kuffner and Erich Kaiser identified the minor tobacco alkaloid nicotelline as a terpyridyl derivate.

Edgar Lederer (1908-1988) received his $\mathrm{PhD}$ at the University of Vienna in 1930. Thereafter, he worked with Richard Kuhn at Heidelberg. In 1933, Lederer emigrated from Heidelberg to Paris. He became director at the Centre National de la Recherche Scientifique. Lederer applied the chromatographical method to the isolation of many natural products, such as carotenoids (astracene from red boiled lobster shells, vitamin A2), lipids and peptides of microbes, pheromones, etc. [63].

Léo Edmond Marion (1899-1979) was a Canadian organic chemist. He was born in Ottawa, studied at Queen's and McGill University and spent a year at the University of Vienna. After his return to Canada, Marion became Richard Helmuth Frederick Manske's (1901-1977) assistant at the National Research Council Laboratories (NRC). When Manske left the NRC in 1942, Marion became chief organic chemist. His dedication to basic research enabled him to build an internationally recognized school of alkaloid chemistry [64].

Matthias Pailer (1911-2011) received his doctorate in 1936 and habilitated after wartime interruptions in 1949. In 1971, he was appointed Chair of the Institute of Pharmaceutical Chemistry in Vienna. Besides great achievements in the field of structure elucidation of complex natural products, Pailer had also considerable success in organic synthesis and analytics. Prof. Pailer made a decisive contribution to determining the constitution of the emetines and cephalins, evonine, and evonoline, as well as two alkaloids from Cortex Condurango, Kondurangamin A and B [65].

Hans Eduard Schmid (1917-1976) was born in Gränichen, Switzerland, but moved to Vienna in 1926. From 1935 on, he studied chemistry at the University of Vienna, and in 1941, he earned his doctoral degree with a thesis on coumarin. The following year, he went to the University of Zurich as assistant to Paul Karrer. There, he habilitated in 1944. He was particularly concerned with the structure elucidation of natural products from plants and insects, such as curare alkaloids and toxiferines [66].

Already during World War II, Späth offered his student Karl Schlögl (1924-2007) a job at the institute, which Schlögl accepted. Schlögl spent 1954-1955 at the University of Manchester where he dealt with organometallic compounds. The occupation with ferrocene was to be a defining feature of Schlögl's future scientific life [67].

Friedrich Wessely (1897-1967) was a long-term assistant at the IInd Chemical Institute. He habilitated in 1929 and followed Späth as head of the IInd Institute in 1948.
Wessely published several papers on podophyllotoxin and cotoin together with Späth. He was a pioneer in the synthesis of low- and high-molecular peptides. He clarified the structure of pharmacologically important natural products, especially coumarins and flavones, and was concerned with extraneous female sex hormones [68].

\section{Obituary}

Wessely F (1947) Österreichische Chemiker-Zeitung 48:57.

Acknowledgements Open access funding provided by University of Vienna.

Open Access This article is distributed under the terms of the Creative Commons Attribution 4.0 International License (http://creativeco mmons.org/licenses/by/4.0/), which permits unrestricted use, distribution, and reproduction in any medium, provided you give appropriate credit to the original author(s) and the source, provide a link to the Creative Commons license, and indicate if changes were made.

\section{References}

1. Rosner R (2004) Chemie in Österreich 1740-1914. Böhlau, Wien, p 87

2. Soukup RW (2006) Lieben symposium "Exploring science in central europe around 1900: circles-schools-people". Austrian Academy of Sciences, Vienna

3. Hlasiwetz H (1861) Liebigs Ann Chem 119:199

4. Barth L, Kretschy M (1880) Monatsh Chem 1:99

5. Weidel H (1873) Liebigs Ann Chem 165:328

6. Weidel H (1879) Ber Dtsch Chem Ges 12:410

7. Weidel H, Cobenzl A (1880) Monatsh Chem 1:844

8. Herzig J, Meyer H (1894) Monatsh Chem 15:613

9. Herzig J, Meyer H (1894) Monatsh Chem 16:599

10. Herzig J, Meyer H (1894) Monatsh Chem 18:379

11. Wegscheider R (1882) Monatsh Chem 3:789

12. Rosner R (2004) Chemie in Österreich 1740-1914, vol 163. Böhlau, Wien, p 152

13. Soukup RW (2004) In: Fuks E, Kohlbauer G (eds), Die Liebens. 150 Jahre Geschichte einer Wiener Familie. Böhlau, Wien, p 125

14. Lieben A (1870) Liebigs Ann Chem Suppl 7:218

15. Lieben A (1870) Liebigs Ann Chem Suppl 7:377

16. Späth E (1927) Geschichte der Chemie in Österreich. Österreichische Akademie der Wissenschaften, Wien, p 8

17. Zeisel S (1883) Monatsh Chem 4:162

18. Zeisel S (1886) Monatsh Chem 7:557

19. Skraup ZH (1880) Monatsh Chem 1:316

20. Soukup RW (2004) In: Soukup RW (ed), Die wissenschaftliche Welt von gestern. Böhlau. Wien, p 73

21. Späth E (1919) Monatsh Chem 40:129

22. Heffter A, Capellmann R (1905) Ber Dtsch Chem Ges 38:3634

23. Manske RHF, Holmes HL (eds) (1953) The alkaloids. Academic Press, Cambridge, p 324

24. Soukup RW (2004) Die wissenschaftliche Welt von gestern. Böhlau, Wien, p 209

25. Soukup RW (2004) Österreichisches Biographisches Lexikon Bd 12:444

26. Wegscheider R, Späth E (1909) Monatsh Chem 30:825

27. Späth E (1914) Monatsh Chem 35:463

28. Späth E (1915) Monatsh Chem 36:1

29. Wegscheider R, Späth E (1916) Monatsh Chem 37:277 
30. Rieth R (1861) Liebigs Ann Chem 120:247

31. Fischer O (1910) Festschrift zum 80. Geburtstag des Prinzregenten Luitpold. Chem Zentr 1:957

32. Späth E (1919) Monatsh Chem 40:351

33. Archiv der Universität Wien (1922) Signatur PH S 34.6: Korrespondenz, Kommissionssitzungen und -protokolle zur Wiederbesetzung der II. chemischen Lehrkanzel nach Prof. Wilhelm Schlenk

34. Späth E (1919) Monatsh Chem 40:19

35. Späth E, Leithe W, Ladeck F (1928) Ber Dtsch Chem Ges 61:1698

36. Späth E (1931) Ber Dtsch Chem Ges 64:370

37. Späth E (1931) Ber Dtsch Chem Ges 64:1123

38. Späth E (1931) Ber Dtsch Chem Ges 64:2034

39. Späth E, Kahovec L (1934) Ber Dtsch Chem Ges 67:1501

40. Späth E, Tschelnitz E (1921) Monatsh Chem 42:251

41. Späth E, Bretschneider H (1928) Ber Dtsch Chem Ges 61:327

42. Späth E, Kesztler F (1937) Ber Dtsch Chem Ges 70:704

43. Späth E, Wenusch A, Zajic E (1936) Ber Dtsch Chem Ges 69:393

44. Späth E, Mamoli L (1936) Ber Dtsch Chem Ges 69:1082

45. Späth E, Hromatka O (1929) Ber Dtsch Chem Ges 62:325

46. Späth E, Gruber W (1938) Ber Dtsch Chem Ges 71:106

47. Fritz K (1938) Rektoratsinauguration, Archiv der Universität Wien, $\mathrm{p} 12$

48. Feichtinger J, Matis H, Sienell S, Uhl H (2013) Die Akademie der Wissenschaften in Wien 1938 bis 1945. ÖAW, p 161

49. Chakraborty DP (2018) Prafulla Kumar Bose (1898-1983) elected fellow 1944, Indian National Science Academy: http://insaindia. res.in/BM/BM13_8817.pdf. Accessed Dec 4, 2018

50. Bestandsrecherche Ludwig Hermann Bretschneider in der Datenbank "Verzeichnis der künstlerischen, wissenschaftlichen und kulturpolitischen Nachlässe in Österreich" (2009) http://data.onb. ac.at/nlv_lex/perslex/B/Bretschneider_Hans.htm. Accessed Dec 9, 2018

51. Austria Forum, Alfred Burger (2018) https://austria-forum.org/af/ AustriaWiki/Alfred_Burger_(Chemiker). Accessed Dec 5, 2018

52. Torbjörn N (1990) Phytochemistry 29:1713

53. Oberkofler G, Goller P (1994) Fritz Feigl (1891-1971) Notizen und Dokumente zu einer wissenschaftlichen Biographie. Zentralbibliothek für Physik, Wien, p 25
54. Späth E, Galinovsky F (1932) Ber Dtsch Chem Ges 65:1526

55. Soukup RW, Soukup K (2015) Prog Chem Org Nat Prod 100:477

56. Wilhelm Exner Medaillen Stiftung (2018) Otto Hromatka: http:// www.wilhelmexner.at/preistraeger_107.html. Accessed Dec 5, 2018

57. Science History Institute (2018) Percy Lavon Julian: https://www. sciencehistory.org/historical-profile/percy-lavon-julian. Accessed Dec 5, 2018

58. Korotin I (2016) biografiA. Lexikon österreichischer Frauen, vol 2. Böhlau, Wien, p 1630

59. Späth E, Gandini-Kesztler F (1952) Monatsh Chem 83:1301

60. Späth E, Gandini-Kesztler F (1960) Monatsh Chem 91:1150

61. Soukup RW (2004) Die wissenschaftliche Welt von gestern. Böhlau, Wien, p 275

62. Soukup RW, Soukup K (2015) Prog Chem Org Nat Prod 100:468

63. Lederer E (2007) Itinéraire d'un biochimiste français. éditions Publibook

64. Edwards OE (2013) The Canadian Encyclopedia 7

65. Fleischhacker W (2011) Sci Pharm 79:387

66. Isler O (1976) Verhandlungen der Schweizerischen Naturforschenden Gesellschaft 156(1):131

67. Zentralbibliothek für Physik (2014) 1924 Ein guter Jahrgang, Karl Schlögl: https://www.zbp.univie.ac.at/webausstellung/1924/ Karl_Schloegl.htm. Accessed Dec 5, 2018

68. Schuster I (2017) Kaleidoskop der Naturwissenschaft: Fritz Wessely: http://scienceblog.at/vor-76-jahren-friedrich-wessely\% C3\%BCber-den-status-der-hormonchemie\#.XAgJ3eTQZPY. Accessed December 5, 2018

Publisher's Note Springer Nature remains neutral with regard to jurisdictional claims in published maps and institutional affiliations. 